\title{
Tinjauan Kritis tentang Program Tayangan Anak di Televisi
}

\author{
Dedeh Fardiah
}

\section{ABSTRACT}

\begin{abstract}
In the field of mass communication, studies concerning children and mass media always provide interesting perspectives, especially concerning the effect of television viewing. Each year, communication experts, psychologists, as well as parents attended this issue seriously. From communication and psychological perspectives, televisions were blamed as the source of the problem due to bad program qualities as well as high frequent of TV violence, and sexual content. Employing Critical Theories for analyzing device, this article addresses the map of children program on $T V$, and how the program was packed. Children program on TV still face many obstacles, including the challenge thrown by rating on media market industries.
\end{abstract}

Kata kunci: televisi, tayangan anak, teori kritis

\section{Latar Belakang Masalah}

Media massa telah menjadi fenomena tersendiri dalam proses komunikasi massa dewasa ini bahkan ketergantungan manusia pada media massa sudah sedemikian besar. Media komunikasi massa abad ini yang tengah digandrungi masyarakat adalah televisi. Joseph Straubhaar \& Robert La Rose dalam bukunya Media Now menyatakan;

The average person spend 2600 hours per year watching TV or listening to Radio. That's 325 eight-hourdays, a full time job. We spend another 900 hours with other media, including newspapers, books, magazines, music, film, home video, video games, and the internet; that's about hours of media use-more time than we spend on anything else, including working or sleeping (Straubhaar \& La Rose, 2004 : 3)
Kondisi di atas dapat dipahami, sebab ternyata berdasarkan penelitian di beberapa negara menggambarkan bahwa aktivitas menonton televisi menjadi kegiatan utama dalam menghabiskan waktu bersantai setiap individu, sebagaimana dapat dilihat pada uraian berikut ;

If we consider the social context to television, it is possible to argue that television is important to its audience. In the UK, adults (over the age of 16), spend on average twenty hours a week watching television (Social Trends 2003). Adults spend nearly two hours of the day watching television whilst not doing anything else... Although leisure activities include other activities apart from watching television, the fact that adults spend approximately twenty hours a week doing just that indicates that television is the number one leisure activity for the British public. Similar figures can be shown for other Western societies such as America, and Northern Europe, although Southern Europe traditionally 
scores lower in terms of levels of television viewing (Hill, 2005 : 129).

Menurut uraian di atas, dapat diinterpretasikan bahwa jika mempertimbangkan konteks sosial televisi sangat mungkin untuk berargumentasi bahwa televisi itu penting bagi audiensnya. Di Inggris orang dewasa (di atas 16 tahun) menghabiskan rata-rata 20 jam per minggu untuk menonton televisi (Social trend 2003.) Orang-orang dewasa menghabiskan waktu sekitar 2 jam sehari menonton televisi, tanpa melakukan hal lainnya. Kebanyakan orang menonton televisi bersama anggota keluarga atau teman. Fakta bahwa orang dewasa kira-kira menghabiskan 20 jam per minggu menunjukkan bahwa televisi merupakan aktivitas santai nomor satu untuk publik Inggris. Angka yang sama dapat ditunjukkan bagi masyarakat Barat lainnya seperti Amerika dan Eropa Utara, meskipun Eropa Selatan skornya lebih rendah dalam tingkat menonton televisi.

Di Indonesia, berdasarkan survei $A G B$ Nielsen tahun 2006, ternyata 42,86\% sampai $95,83 \%$ masyarakat Indonesia suka menonton televisi. Hasil ini lebih lanjut dijelaskan bahwa "Hampir 8 dari 10 orang dewasa di kota-kota besar menonton televisi setiap hari dan 4 dari 10 orang mendengarkan radio"1. Pada temuan lain, Hoffman menyatakan bahwa hampir tidak ada orang yang dipaksa menonton televisi atau dipaksa membeli alat televisi, sehingga sebelum krisis moneter 80 $\%$ masyarakat Indonesia sudah biasa menonton televisi (Hoffman, 1999: 74).

Televisi memiliki beberapa kelebihan sebagai media massa, sehingga menjadi media favorit pemirsa. Secara fisik, kehadiran televisi dapat mempengaruhi masyarakat seperti halnya media massa pada umumnya, sebagaimana dijabarkan oleh Steven H.Chafee tentang media massa bahwa kehadiran media massa secara fisik berpengaruh pada efek ekonomis, efek sosial, efek pada penjadwalan kegiatan, efek pada penyaluran/ penghilangan perasaan tertentu, dan efek perasaan orang terhadap media (Rakhmat, $1996: 20$ )

Temuan Nielsen Media Research (2005) menunjukkan, televisi memiliki daya penetrasi jauh lebih besar daripada media informasi lainnya.
Penetrasi televisi mencapai 91,7\%, sedang surat kabar, majalah, tabloid, sinema, dan radio, masingmasing hanya mencapai $25,7 \%, 22,9 \%, 16,1 \%, 1,2 \%$, dan $42,1 \%$. Kuatnya penetrasi TV itulah yang menyebabkannya menjadi media paling berpengaruh dalam mendongkrak omzet dunia industri televisi. ${ }^{2}$

Beberapa kelebihan televisi seperti; sifatnya yang audiovisual, dapat disaksikan beramai-ramai dan tidak memerlukan banyak cost merupakan faktor pendukung diterimanya televisi sebagai media favorit bagi pemirsa. Kebutuhan untuk mendapatkan hiburan, pengetahuan, dan informasi secara mudah, dapat diperoleh melalui televisi, selain selalu tersedia dan amat mudah diakses, juga menyuguhkan banyak pilihan acara dari tiap stasiun televisi, sehingga pemirsa tinggal memilih acara yang dibutuhkan, disukai, dan sesuai dengan selera, tidak terkecuali bagi anak-anak.

Beberapa penelitian menunjukkan, dari tahun ke tahun jumlah jam menonton televisi pada anak mengalami peningkatan. Yayasan Kesejahteraan Anak Indonesia (YKAI) mencatat, saat ini ratarata anak usia sekolah dasar menonton televisi antara 30 hingga 35 jam setiap minggu. Artinya, pada hari-hari biasa mereka menonton tayangan televisi lebih dari empat hingga lima jam sehari. Sementara, di hari Minggu bisa tujuh sampai delapan jam. Padahal, banyak acara TV tergolong kurang aman dan kurang bersahabat bagi anak anak $^{3}$

Relasi anak dengan televisi telah menjadi persoalan yang problematik. Di satu sisi, televisi menjadi sarana transferensi ide, nilai, norma, dan transformasi mental ke arah penyadaran, pencerahan, dan kemajuan kehidupan. Namun, di sisi lain, ia dapat menularkan pengaruh buruk yang mendegradasikan format kemanusiaan dan kemampuan berpikir anak(Venus dalam Mulyana \& Ibrahim, 1997 : 175)

Berbagai kekhawatiran yang muncul tentang tayangan televisi bagi anak-anak, telah lama menjadi perdebatan. Perdebatan makin mencuat sejak maraknya televisi swasta di Indonesia dan terjadinya peristiwa stragis seorang anak yang meninggal dunia setelah teman-temannya 
memperlakukan korban seperti tayangan Smack Down di televisi ${ }^{4}$. Peristiwa ini hanyalah salah satu dari sekian alasan tentang kekhawatiran efek tayangan televisi.

Beberapa alasan lain yang turut menjadi kekhawatiran diantaranya bahwa:

(1) Anak-anak acapkali dijadikan sasaran ekspansi pasar melalui media televisi, karena merupakan sasaran proses konsumsi jangka panjang, mengingat usia hidupnya yang masih lama.

(2) Anak-anak masih dalam proses pengembangan kepribadian, sehingga sangat mudah dipengaruhi oleh berbagai hal, karena anak-anak lebih mengandalkan emosi dibandingkan rasionalitas dalam pengambilan keputusan.

(3) Anak-anak semakin terjerat menjadi objek barang-barang industri. Tak heran, banyak anak-anak yang terobsesi untuk ingin terus mengonsumsi apa yang dilihatnya di televisi. Mulai dari ingin makan di waralaba fastfood terkenal hingga membeli mainan robot seperti Power Rangers, boneka Dora, atau Spongebob.

(4) Tayangan televisi yang melibatkan anak hanya menawarkan sebuah khayalan. Anak-anak dikonstruksi dengan gaya hidup yang ditawarkan berupa khayalan, seperti rumah mewah, baju mahal, dsb.

(5) Tayangan televisi juga dianggap banyak menebarkan unsur-unsur kekerasan dan pornografi bagi anak-anak. (http:// www.parasindonesia.com).

Beberapa alasan di atas inilah yang di antaranya menjadi kecemasan utama para orang tua, guru, dan masyarakat pada umumnya. Maka, tak heran jika sejak Hari Anak Nasional, pada 23 Juli 2006, dicanangkan "Satu Hari tanpa Televisi" di mana pada hari ini seluruh masyarakat dilibatkan partisipasinya dalam mematikan televisi demi anak-anaknya.

Menurut Pendapat guru besar Psikologi Universitas Indonesia, Sarlito Wirawan Sarwono,"Televisi itu kontroversial jika dikaitkan dengan anak. Televisi dipercaya memberi pengaruh buruk bagi anak kecil. Banyak orang mengeluh soal televisi. Tetapi, televisi walaupun jelek, juga tetap ditonton. Ini kenyataan yang tidak terhindarkan, pengaruh buruk televisi itu sebenarnya sudah disadari para orang tua. Soal ini pun sudah kerap dibahas dalam berbagai seminar atau diskusi. Namun, televisi ternyata tetap menjadi salah satu alternatif tontonan di rumah". ${ }^{5}$

Relasi antara televisi dan anak inilah yang, menurut pengamatan penulis, akan selalu menarik untuk dikaji. Oleh karena itu, tulisan sederhana ini hendak mencermati "Bagaimana wacana anak ditampilkan dalam program tayangan anak di televisi swasta nasional?"

\section{Kerangka Pemikiran}

\subsection{Industri Televisi}

Televisi merupakan perkembangan media audiovisual yang ditemukan oleh Paul Nipkow dari Jerman pada 1884. Di negara-negara Eropa, Amerika, dan negara maju lainnya, puluhan saluran TV tersedia dan dapat dipilih sekehendak hati. Mereka bersaing untuk menyajikan acara-acaranya yang terbaik agar dapat ditonton oleh masyarakat yang semuanya dilandasi perhitungan bisnis.

Sejarah televisi sebelumnya belum terlalu lama di dunia. Demonstrasi pertama siaran televisi dilakukan di Amerika Serikat dan Inggris. Dengan berbagai percobaan, siaran komersial televisi berkembang setelah Perang Dunia II. Di negara kita, televisi diperkenalkan tahun 1962. Masuknya televisi ke Indonesia (tepatnya ke Jakarta), pada waktu itu, berhubungan erat dengan peristiwa olahraga Asia ke-4 (The $4^{\text {th }}$ Asian Games) di mana Indonesia mendapat giliran menjadi tuan rumah. Peresmian televisi bersamaan dengan dibukanya peristiwa olahraga itu oleh Presiden Soekarno, 24 Agustus 1962. Tujuan utama pengadaan televisi ialah untuk meliput semua kegiatan kejuaraan dan pertandingan selama pesta olahraga berlangsung. (Kuswandi, 1996 : vi)

Di Indonesia, kecenderungan televisi swasta sudah mulai mengarah kepada sistem Amerika. Ini dimulai dari garapan-garapan sinetron, kuis, dan beberapa acara hiburan lainnya. Cara seperti ini 
memang sangat menguntungkan bagi stasiun TV tersebut, karena semuanya dapat dilakukan berdasarkan pertimbangan-pertimbangan bisnis, yaitu untung dan rugi. Tidak dapat dipungkiri bahwa televisi merupakan suatu bisnis, maka tak heran kalau Bignell (2004 : 43) menyebutnya television today is a centralized business.

\subsection{Lapisan-Lapisan yang Melingkupi Industri Media Massa}

Pekerjaan media pada hakikatnya mengonstruksikan realitas di mana isinya merupakan hasil para pekerja media mengonstruksikan realitas yang dipilihnya, maka pekerjaan media massa adalah "menceritakan" peristiwa-peristiwa, sehingga seluruh isi media adalah realitas yang telah dikonstruksikan. Pembuatan pesan di media, tak lebih dari penyusunan realitas-realitas, hingga membentuk sebuah cerita. Isi media merupakan hasil konstruksi realitas dengan bahasa sebagai perangkat dasarnya. Bagi media, bahasa bukan sekadar alat komunikasi untuk menyampaikan fakta, informasi atau opini. Bahasa juga bukan sekedar alat komunikasi untuk menjabarkan realitas, namun juga menentukan gambaran atau citra tertentu yang hendak ditanamkan kepada publik.

Media, sesungguhnya, memainkan peran khusus dalam mempengaruhi budaya tertentu. Peran media sangat penting, karena menampilkan sebuah cara dalam memandang realita. Para

\section{Gambar 1: Hierrarchy of Influence}

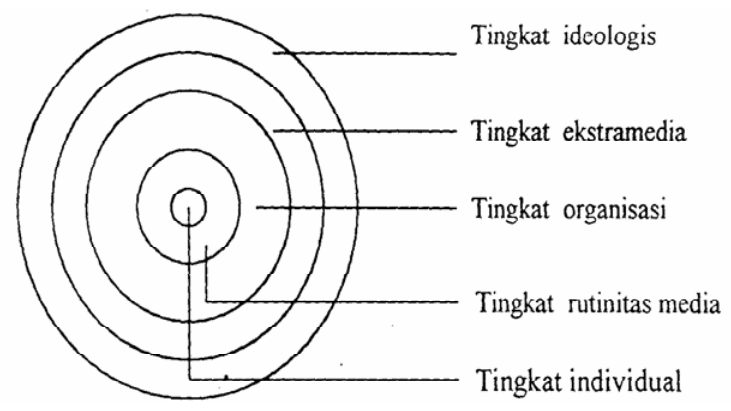

produser mengendalikan isi medianya melalui caracara tertentu untuk menyandikan pesan-pesan. Pada dasarnya, ketika media massa menyampaikan pesannya, media tersebut memiliki orientasi tertentu yang dilatarbelakangi oleh beberapa faktor. Kecenderungan atau perbedaan setiap media dalam memproduksi pesan kepada khalayak dapat diketahui dari pelapisan-pelapisan yang melingkupi institusi media. Dalam hal ini, Pamela Shoemaker dan Stephen D.Reese membuat model "Hierrarchy of Influence"; (Shoemaker dan Reese dalam Susilo, 2000:19)

(1) Pengaruh Individu-individu pekerja media, di antaranya adalah karakteristik pekerja komunikasi, latar belakang personal, dan profesional.

(3) Pengaruh rutinitas media, apa yang dihasilkan oleh media massa dipengaruhi oleh kegiatan seleksi-seleksi yang dilakukan oleh komunikator, termasuk tengat (deadline) dan rintangan waktu yang lain, keterbatasan tempat (space)

(4) Pengaruh organisasional, salah satu tujuan yang penting dari media adalah mencari keuntungan material. Tujuan-tujuan dari media akan berpengaruh pada isi yang dihasilkan.

(5) Pengaruh dari luar organisasi media. Pengaruh ini meliputi lobi dari kelompok kepentingan terhadap isi media pseudoevent dari public relations dan pemerintah yang membuat peraturan-peraturan dibidang pers.

(6) Pengaruh ideologi, ideologi merupakan sebuah pengaruh yang paling menyeluruh dari semua. Ideologi di sini diartikan sebagai mekanisme simbolik yang menyediakan kekuatan kohesif yang mempersatukan dalam masyarakat. (Shoemaker,Reese, 1991 dalam Susilo, 2000 : 19-20)

\subsection{Teori Kritis Marxis}

Pandangan Marxis perihal masyarakat dan perihal media berkembang sepanjang abad kedua puluh. Pandangan Marxis berfokus pada determinisme ekonomi, relasi kelas, penggunaan kontrol dan kekuasaan dalam struktur sosial yang terkadang digambarkan sebagai teori kontrol. 
Graeme Burton, mengambarkan bahwa fenomena televisi sebagian mencontohkan gagasan bahwa masyarakat digerakkan oleh kepentingan pemilik modal dan kekuatan ekonomi. Televisi komersial didanai oleh sebuah sistem kapitalis. Program-program televisi mendiskusikan pengaruh kekuatan ekonomi. Perkembanganperkembangan dalam dunia televisi baik itu jenis program baru atau perkembangan digital dan channel baru digerakkan oleh kepentingankepentingan ekonomi: menciptakan pasar-pasar baru, menghasilkan lebih banyak uang.

Televisi merepresentasikan relasi kelas, kurang lebih secara eksplisit. Komedi situasi (sitcom) keeping up appearance membuat lucu aspirasi-aspirasi kelas menengah Ny. Bouquetkarenanya memberi kontribusi bagi sirkulasi pelbagai gagasan tentang kelas.

Berita menciptakan gagasan ihwal orang elite dengan cara menampilkan beberapa orang, dan bukan yang lain, serta dengan menampilkan orang-orang tersebut dengan cara tertentukeluarga yang mewah, misalnya. Televisi merepresentasikan hubungan kekuasaan secara eksplisit, misalnya bagaimana program televisi menunjukkan cara laki-laki memperlakukan perempuan.

Secara implisit, bisa dikemukakan bahwa ini merupakan satu cara menjalankan kekuasaan atas unit masyarakat yang luas, yakni dengan merepresentasikan cara berpikir dan berperilaku tertentu seolah-olah alami, sementara cara lain tidak alami. Penyikapan yang berbeda merupakan ekspresi ideologi. (Burton, dalam Rahmawati, 2007:31)

\subsection{Ekonomi Politik Media}

Pendekatan ekonomi politik merupakan sebuah kajian yang diidentifikasi sebagai kelompok pendekatan kritis (McQuail, 1996:82). Pendekatan ekonomi politik memokuskan pada kajian utama tentang hubungan antara struktur ekonomi-politik, dinamika media, dan ideologi media itu sendiri. Perhatian penelitian ekonomi politik diarahkan pada kepemilikan, kontrol, serta kekuatan operasional pasar media. Dari titik pandang ini, institusi media massa dianggap sebagai sistem ekonomi yang berhubungan erat dengan sistem politik.

Karakter utama pendekatan ekonomi politik adalah produksi media yang ditentukan oleh: pertukaran nilai isi media yang berbagai macam di bawah kondisi tekanan ekspansi pasar dan juga ditentukan kepentingan ekonomi-politik pemilik modal dan pembuat kebijakan media (Garnham dalam McQuail, 1996:82). Berbagai kepentingan tersebut berkaitan dengan kebutuhan untuk memperoleh keuntungan, sebagai akibat dari adanya kecenderungan monopolistis dan proses integrasi, baik secara vertikal maupun horisontal.

\subsection{Rating dalam Lingkaran Ideologi Pasar Media Massa}

Kepercayaan pada rating yang dihasilkan lembaga riset telah dianggap sebagai suatu hal yang lazim (commons) bagi kalangan media massa, khususnya televisi, sehingga, jika televisi dikritik sebagai penghasil teks-teks kultural rendahan atau low taste, content, biasanya tameng yang segera dikedepankan adalah rating. (Iqbal \& Panjaitan, 2006: 48).

Televisi merupakan industri yang sangat berorientasi pada jumlah penonton terbesar. Jumlah penonton inilah yang bisa dibawa dan ditawarkan kepada pemasang iklan. Ketika suatu program acara memiliki rating tinggi. Itu artinya, banyak orang kendatipun sama sekali tidak ada jaminan orang yang menonton televisi sebagai orang yang betul-betul sedang menyaksikan program acara televisi apalagi menyukainya.

Oleh karena itu, pandangan pihak televisi atau lembaga riset khalayak meyakini bahwa ada selera umum/universal di masyarakat melalui tindakan menonton meskipun ada berbagai kondisi yang membuat orang tidak selamanya fokus atau bersikap selektif pada acara-acara televisi.

Dalam rating perilaku audiens yang menonton seolah-olah diposisikan sebagai variabel independen, sedangkan dalam survei audiens dianggap sebagai variabel terikat (pasif), padahal, menurut perspektif Budiman, "menonton televisi tampaknya tidak lagi disimpulkan sebagai proses 
yang bersifat pasif, melainkan sebuah proses sosial yang aktif“"(Budiman, 2002: 132)

\subsection{Tayangan Anak yang Ideal}

Anak-anak sebagai khalayak televisi selalu dipandang sebagai kasus khusus, karena anakanak diasumsikan mudah tersugesti dan rentan terhadap pengaruh, oleh karena itu regulasi dan program tayangan anak-anak harus memenuhi kriteria-kriteria tertentu. Berdasarkan undangundang Televisi Anak tahun 1990 (Chen, 2005: xviii) menyebutkan bahwa program televisi anak harus memenuhi ketentuan sebagai berikut :

(1) Harus menanggapi kebutuhan anak untuk tahu;

(2) memenuhi kebutuhan harga diri;

(3) memenuhi kebutuhan akan ketrampilan mengatasi berbagai masalah;

(4) membangkitkan semangat kaum muda agar melibatkan diri dalam kiat memperbaiki lingkungan masyarakat, kota dan bumi;

(5) membantu anak-anak memahami hak-hak dan kewajiban-kewajiban warga negara;

(6) stasiun-stasiun televisi harus membatasi banyaknya iklan yang ditayangkan pada acara anak-anak;

(7) harus menayangkan beberapa program yang memenuhi kebutuhan pendidikan anak-anak. Selanjutnya, dalam literatur Indonesia JB.

Wahyudi mengemukakan karateristik tayangan anak-anak meliputi :

(1) Mata acara TV yang diperuntukkan bagi anakanak, selain harus disajikan pada saat anakanak belum tidur, isi pesannya, baik audio maupun visualnya, harus sesuai dengan selera anak-anak. Di sini pengelola, baik perencana program, perencana penyajian (planning programming) harus menyadari bahwa pada dirinya terletak tanggung jawab moral terhadap masyarakat termasuk anak-anak. Jadi perencanaan program harus dilandasi asas manfaat program itu bagi pemirsa, khususnya bagi anak-anak;

(2) Program TV harus mampu memberikan dasar pemikiran yang jelas, sesuai dengan norma dan etika yang berlaku dan mengapa cerita serta adegan itu dibuat dan disajikan.

(3) Progran TV yang cocok untuk anak-anak adalah perkembangan ilmu pengetahuan dan teknologi, sejarah perjuangan bangsa, nilainilai budaya bangsa, cerita seorang ksatria, seni budaya bangsa dan nilai-nilai pancasila dan UUD 1945. (Wahyudi dalam Mulyana dan Ibrahim, 1997:199-200)

\section{Pembahasan}

Perkembangan pertelevisian di Indonesia dekade terakhir ini memang amat menarik. Televisitelevisi swasta baru bermunculan melengkapi dan memperkaya TV yang sudah ada. Tercatat, TV yang ada di Indonesia adalah TVRI, RCTI, SCTV, TPI, AN-Teve, Indosiar, Trans TV, Lativi, Trans 7, Global TV, dan Metro TV, bahkan TV-TV lokal di seluruh propinsi di Indonesia mulai bermunculan seperti Cahaya TV Banten, Jak-TV Jakarta, Bali $T V$, Bandung TV, Jogja TV, dan banyak lagi.

Dunia penyiaran Indonesia tengah mengalami perubahan luar biasa. Nilai-nilai komersial menjadi patokan utama dalam industri penyiaran di Indonesia, khususnya industri pertelevisian. Perubahan tersebut ditandai, antara lain, dengan pergeseran cara pandang terhadap masyarakat oleh stasiun televisi. Sejalan dengan perkembangan industri televisi komersial, publik berubah menjadi khalayak, yakni kelompok masyarakat yang dianggap hanya berdasarkan kategorisasi tertentu. Masyarakat dipandang sebagai konsumen yang harus digembirakan, disenangkan, dan dimanjakan dengan "diikuti keinginannya”, sehingga membentuk watak masyarakat sebagai sasaran industri pertelevisian. Dalam hal ini, masyarakat menuntut untuk disenangkan, keinginannya dipenuhi, mimpi-mimpinya divisualisasikan, dan stasiun televisi komersial mencoba untuk memenuhi tuntutan khalayak tersebut.

Realitas tersebut di atas membuat peran media massa yang begitu besar selalu berbenturan dengan kepentingan-kepentingan tertentu, baik penguasa, politisi, pengusaha, bahkan organisasi masyarakat. Berdasarkan jajak pendapat yang dilakukan surat kabar Kompas ditemukan bahwa tidak ada independensi absolut dalam kehidupan media 


\section{Gambar 2 Grafik Persentase Jajak Pendapat Orientasi Media Massa}

\begin{tabular}{|c|c|c|c|}
\hline Jakarta [ & 67,6 & 24,1 & 8,3 \\
\hline Yogyakarta & 68,0 & 20,0 & 12,0 \\
\hline Surabaya [ & 68,0 & 23,1 & 8,9 \\
\hline Medan [ & 69,4 & 20,4 & 10,2 \\
\hline Padang [ & 61,1 & 27,8 & 11,1 \\
\hline Banjarmasin & 69,2 & 23,1 & 7,7 \\
\hline Pontianak & 75,0 & 25,0 & 0,0 \\
\hline Manado [ & 75,0 & 25,0 & 0,0 \\
\hline Makassar [ & 69,6 & 23,9 & 6,5 \\
\hline Jayapura [ & 55,6 & 33,3 & 11,1 \\
\hline
\end{tabular}

massa. Fenomena ini bisa dilihat dari orientasi media saat ini di mana sebagian masyarakat menilai media massa cenderung berorientasi pada aspek komersial ketimbang idealisme media massa, seperti tampak pada gambar 2 .

Diagram di atas mencerminkan bahwa media massa rata-rata $67,85 \%$ dianggap sebagai media yang mengutamakan ideologi komersial. Hal ini tidak ada pengecualian bagi televisi sebagai media yang memiliki penetrasi amat tinggi di masyarakat. Dalam perolehan belanja iklan, televisi menduduki posisi tertinggi dibandingkan media massa lainnya sebagaimana dapat dilihat pada gambar 3.

Gambar 3, memperkuat argumen bahwa televisi sangat tergantung hidupnya dari iklan konsekuensinya program acara seringkali bergantung pada rating di mana rating ini seringkali menjadi patokan para pemasang iklan untuk beriklan di televisi. "Pada situasi seperti ini seringkali permasalahan idealisme versus bisnis terangkat ke atas, sudah lumrah terjadi para

\section{Gambar 3 Grafik Belanja Iklan Mediadi A sia Pasifik 2006}

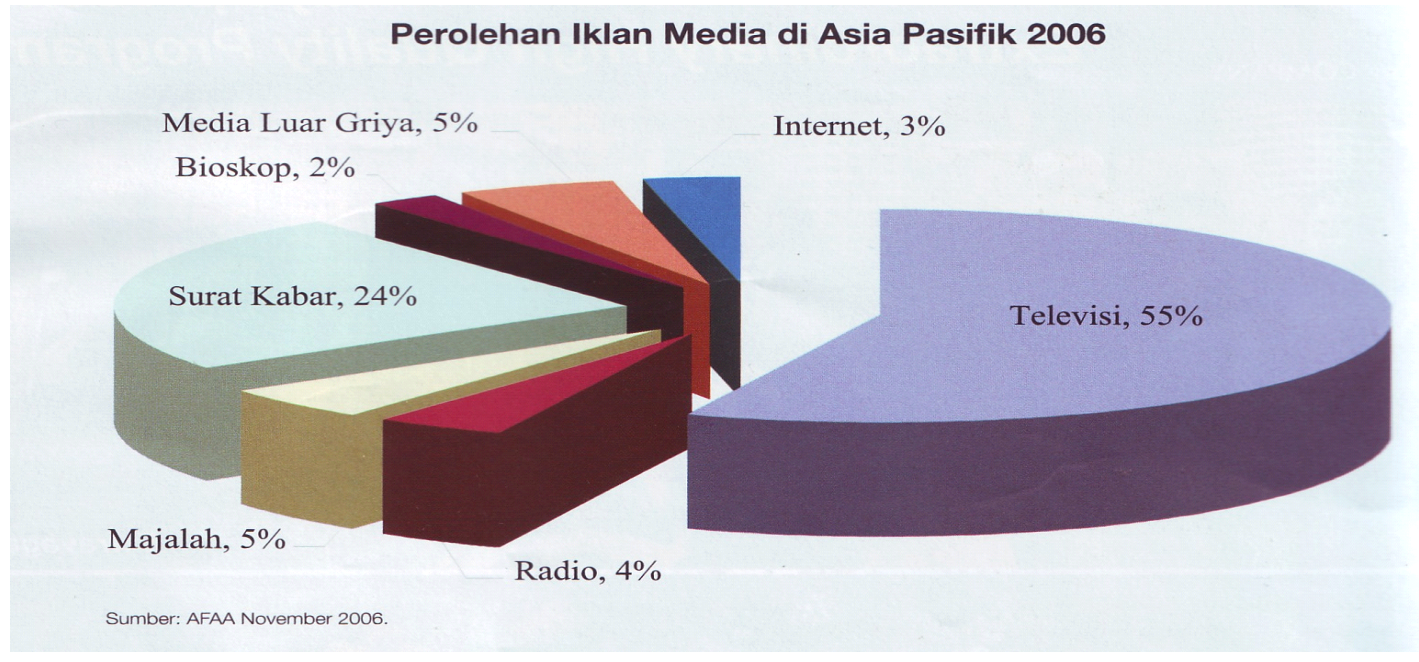




\section{Gambar 4: Digram Program TV Favorit}

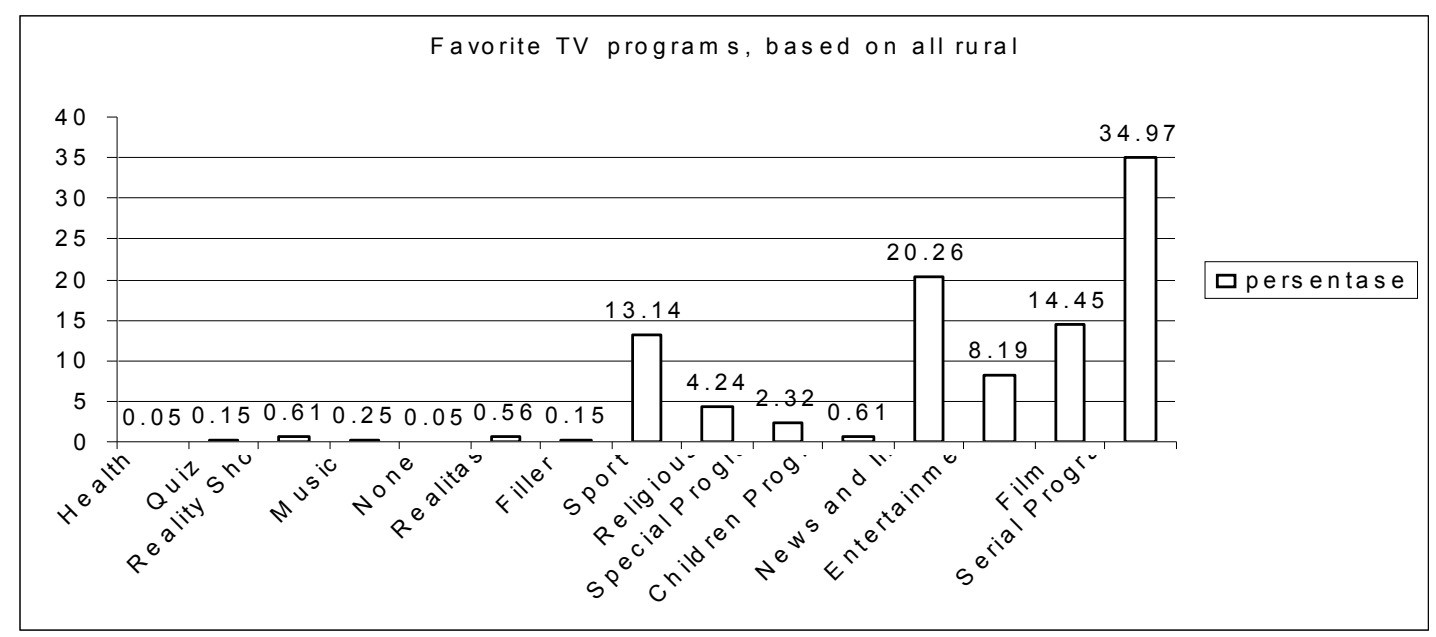

Sumber: Media Scene 2005-2006

perencana program karena terlalu mengacu pada rating telah mengenyampingkan dan meremehkan idealisme..." (Ishadi, 1999: 81).

Bagaimana fenomena ini terjadi? Mari kita cermati, sebagian besar TV di Indonesia menayangkan beragam program acara yang terklasifikasi pada kategori tertentu. Berdasarkan program acara yang menjadi favorit pemirsa

Tabel 1: Precentage of Children's Programs on TV

\begin{tabular}{|c|c|c|c|c|c|}
\hline & Station & $\mathbf{1 9 9 7}$ & $\mathbf{2 0 0 0}$ & $\mathbf{2 0 0 3}$ & $\mathbf{2 0 0 5}$ \\
\hline 1 & TVRI & $7.6 \%$ & $7.1 \%$ & $5.7 \%$ & $7.9 \%$ \\
\hline 2 & RCTI & $1.5 \%$ & $6.0 \%$ & $10.9 \%$ & $14.8 \%$ \\
\hline 3 & SCTV & $4.5 \%$ & $7.7 \%$ & $5.9 \%$ & $14.3 \%$ \\
\hline 4 & TPI & $6.5 \%$ & $8.8 \%$ & $3.5 \%$ & $5.2 \%$ \\
\hline 5 & AN-TV & $0.7 \%$ & $4.0 \%$ & $22.9 \%$ & $17.6 \%$ \\
\hline 6 & Indosiar & $3.4 \%$ & $8.1 \%$ & $6.9 \%$ & $4.5 \%$ \\
\hline 7 & TV-7 & & & $12.2 \%$ & $14.2 \%$ \\
\hline 8 & Trans-TV & & & $6.5 \%$ & $11.6 \%$ \\
\hline 9 & Lativi & & & $8.3 \%$ & $22.5 \%$ \\
\hline 10 & Global TV & & & $2.1 \%$ \\
\hline
\end{tabular}

diperoleh data sebagai pada gambar 4 .

Jika dicermati, maka program anak hanya sebesar $0,61 \%$ saja menjadi perhatian utama program televisi, selebihnya banyak didominasi oleh acara yang sifatnya umum seperti serial program, reality show, film, entertainment, news dan informasi, olah raga, musik dan lain-lain dengan segmentasi orang dewasa. Informasi lain berdasarkan data dari Yayasan Kesejahteraan Anak Indonesia diperoleh gambaran persentase program anak-anak di stasiun swasta yang ada di Indonesia sebagaimana pada tabel 1 .

Berdasarkan tabel 1, dapat dilihat bahwa program anak mendapatkan porsi sedikit dari para pengelola televisi paling banyak hanya $22 \%$ program anak yang ada di televisi dengan persentasenya amat beragam. Tampaknya, produksi acara televisi dalam negeri masih sibuk memberikan tontonan kepada orang dewasa seperti sinetron ataupun paket musik. Padahal, dari segi jumlah, audiens anak-anak jauh lebih besar dibandingkan orang dewasa. Data Komisi Penyiaran Indonesia (KPI) tahun 2004, menunjukkan bahwa:

Meski jumlah jam tayang untuk program anakanak meningkat 13 persen dari tahun sebelumnya 
tetapi jumlah waktu yang dipakai untuk menonton program-program tersebut justru turun sebanyak 15,7 persen. Pada saat bersamaan, waktu yang digunakan anak-anak untuk menonton televisi justru meningkat. Pada kuartal pertama 2004, waktu menonton televisi di kalangan anak kelompok umur 5-9 tahun meningkat dari 2,85 jam menjadi 2,9 jam per hari. Sementara, untuk anak kelompok umur 10-14 tahun meningkat dari 3,13 jam menjadi 3,15 jam per hari. Hal ini berarti, anak-anak menonton televisi bukan menonton program yang dikhususkan untuk anak. Anak-anak justru mendorong naiknya rating untuk program yang bukan ditujukan untuk anak-anak. (Morissan, 2005: 170)

Penelitian yang pernah dilakukan para peneliti dari beberapa negara Asia yang bertema Asian Children's Experience, ini ditemukan beberapa fenomena korelasi antara televisi dan anak, baik di negara China, India, Malaysia, Nepal, Singapore, dan Indonesia. Di Indonesia, fenomena yang muncul digambarkan oleh Guntarto sebagai berikut:

(1) There are no certain special times programmed for children. Peak hours where many children watch television are filled with adult movies which contain a lot of sex, violent scenes, and movie scenarios which are not suitable for them.

(2) For each programme, there is no information concerning the age group intended as viewers (although it has been set in a Ministry of Information decree).

(3) There have been very limited programmes intended for children (only 3.63 per cent compared with total fare in each private television station).

(4) Most of the limited programmes intended for children are of poor quality and do not contain clear educational messages.

(5) There is no standard quality for producing children's programmes.

(6) Commercials, thrillers, and other spots which do not have any relation with the children are still viewed (Guntarto dalam Hogan, 2000:146-147).
Fakta-fakta pada penelitian ini jika diinterpretasikan, menunjukkan bahwa anak-anak tidak diperlakukan sebagai penonton-penonton khusus, di mana tidak ada waktu khusus acara yang diprogramkan untuk anak-anak. Waktu di mana banyak anak menonton televisi diisi dengan tayangan orang dewasa yang banyak mengandung seks, kekerasan, dan tayangan film yang tidak pantas untuk mereka. Penelitian ini juga menyatakan untuk tiap-tiap acara tidak ada informasi ihwal kelompok umur yang boleh menonton. Dari tayangan-tayangan yang ada hanya 3,63\% diperuntukkan untuk anak-anak. Kebanyakan dari tayangan anak-anak ini juga dianggap memiliki mutu rendah dan tidak memuat pesan edukasi yang jelas, tidak ada kualitas standar untuk menghasilkan program anak-anak, dan masih ditontonnya iklan-iklan komersil, tayangan horor bahkan tayangan lain yang tidak berhubungan dengan anak-anak.

Berdasarkan survei AGB Nielsen Media Research menunjukkan bahwa ternyata sejak 2004 program acara anak bertambah menjadi $6,211 \%$. Kemudian tahun 2005 sejumlah 8,846\%, dan di tahun 2006 menjadi 10,448\%. Secara kuantitas, tentu saja hal ini cukup menggembirakan, maka sejak tiga tahun terakhir anak-anak tampaknya mulai diperhitungkan sebagai penonton yang potensial; kehadiran televisi anak kemudian menjadi fenomena baru pada dunia pertelevisian di Indonesia.

Berdasarkan survei penulis terhadap program anak di stasiun televisi swasta pada Februari 2007, terdapat empat stasiun televisi swasta yang mengalokasikan program anak di atas 21-44\%, yaitu Global TV, TPI, Lativi dan Trans 7, selebihnya mengalokasikan sekitar 3-14\% saja untuk tayangan program anak. Belakangan muncul televisi yang mengusung konsep edutainment bagi anak-anak Indonesia, yaitu Televisi Anak Space Toon dengan segmen pasar diperuntukkan bagi anak-anak. Walaupun kemunculan Space Toon ini secara izin operasional menimbulkan polemik perdebatan ihwal hak siaran ke seluruh Indonesia, namun pada kenyataannya sampai detik ini anak-anak di seluruh Indonesia, terutama kota-kota besar, dapat 
menyaksikan tayangan-tayangan anak 16 jam dalam sehari, sehingga program anak yang termuat dalam televisi ini $100 \%$ adalah acara yang diperuntukkan bagi anak-anak.

Kendatipun persentase tayangan anak bertambah secara kuantitas tidak diimbangi dengan meningkatnya jumlah tayangan anak lokal, sampai saat ini masih sangat sedikit program acara anak-anak yang khusus dibuat di dalam negeri. Program acara untuk anak-anak sebagian besar dibeli dari distributor acara televisi asing. Animasi menjadi andalan televisi untuk meraih simpati anakanak. Hampir seluruh televisi memiliki paket animasi di mana pada hari Sabtu dan Minggu jam tayang program animasi ditambah.

Kita bisa menghitung dengan jari berapa jumlah tayangan lokal anak dibandingkan tayangan impor. Dalam hal minat pemirsa terhadap tayangan anak AGB Nielsen Media Research, mencatat, dari 10 top program anak di tahun 2006, tidak ada tayangan anak yang sifatnya lokal yang masuk dalam kategori favorit pemirsa. Namun, hingga Juni 2007 tercatat bahwa dari 10 top program tayangan anak hanya $20 \%$ bersifat lokal, selebihnya impor.

Lalu bagaimana dari sisi kualitas? Tampaknya, program tayangan anak di televisi telah tumbuh dalam dua sisi mata uang sebagai dunia masyarakat industri dan dunia di ruang keluarga yang senantiasa membawa berbagai dilema, baik antara dunia rumah dan industri budaya populer, antara pendidikan dan hiburan, antara nilai keutamaan dan nilai baru, maupun antara pola kebangsaan dan nilai-nilai baru nasionalisme, kelokalan, ataupun globalisme.

Beberapa acara anak yang menjadi favorit pemirsa semuanya adalah jenis animasi dan kebanyakan animasi berasal dari Jepang di antaranya Power Rangers Dino Thunder, Avatar The Legend Of Aang, Dragon Ball Z, Pocket Monsters, Teenage Mutant Ninja Turtles, Chalkzone, semuanya bercerita tentang petualangan yang memuat pertempuran, perkelahian, persaingan. Ada juga perjuangan tokoh cerita dalam membela kejahatan. Setting cerita, tentu saja, bisa kita duga, yang memang sangat berbeda dengan budaya kita.

Di manakah program tayangan lokal? Acara lokal yang tampaknya mulai dilirik pemirsa adalah Laptop si Unyil dan Buku Harian si Unyil (Trans7). Entah karena dari sisi nama program ini mengingatkan pada dua nama besar Si Unyil dan Laptop (jargon yang dipopulerkan oleh Tukul), acara ini mampu meraih pemirsa di urutan nomor 2 (dua) dalam 10 top program tayangan anak-anak. Tentu saja, hal ini menarik untuk dikaji, mengapa tayangan ini masuk dalam hitungan pemirsa?

Ternyata, bila kita simak program acara anak ini memuat konsep tayangan Edutainment (pendidikan tapi menghibur). Setting acara, mengingatkan kita pada tayangan si Unyil di tahun 80-an, dengan tokoh-tokoh populer macam Pak Raden ataupun Pak Ogah. Acara ini dikemas sedemikian rupa dengan racikan pengetahuan umum yang banyak memuat informasi tentang berbagai hal. Misalnya, tentang sejarah lampu, bola, layangan dan lain-lainnya, sekaligus selipan hiburan.

Jadi sebetulnya walaupun terlalu dini untuk mengatakan ini, ternyata tayangan lokal tidak kalah dengan tayangan impor. Hanya saja, bagaimana agar acara-acara semacam itu mendapat porsi di stasiun-stasiun televisi lainnya, bukanlah persoalan gampang. Karena, tak bisa dipungkiri tayangan anak di televisi daya hidupnya sangat bergantung pada pengelola media yang mempersepsikan program-programnya melalui sistem rating, yakni suatu sistem yang mengukur daya kepopuleran program televisi dalam perspektif segmen pasar dan demografi.

Tayangan anak dalam industri televisi di Indonesia masih menghadapi problema ketimpangan antara nilai-nilai ideal sebuah tayangan televisi dengan tuntutan pasar yang harus dihadapi oleh para praktisi penyiaran. Di satu sisi, State regulation yang mengedepankan nilai-nilai ideal menghendaki media sebagai industri dan sebagai alat pemersatu bangsa, pelestarian budaya, menghormati agama, dan adat istiadat, serta melindungi khalayak khusus, yaitu remaja dan anakanak; di sisi lain, para praktisi penyiaran dihadapkan pada market regulation, yang 
menghendaki media sebagai industri dan bagian dari sistem kapitalisme. Maka, logika never ending circuit of capital accumulation dengan rumus M-C-M (Money-Commodities-More Money) menjadi tumpuan atas dasar dua kutub, yaitu pasar khalayak dan pasar industri iklan, sehingga anakanak sebagai pemirsa televisi tidak lebih dari objek bisnis dan menjadi parameter rating sebuah program.

\section{Penutup}

Kita pahami bahwa sisi bisnis televisi memang tidak mungkin dihilangkan sebab dari sanalah pendapatan pengelola TV peroleh. Bagaimana mungkin sebuah tayangan bisa diproduksi secara bermutu tanpa biaya yang besar. Harapan kita adalah bagaimana memadukan aspek komersial di satu sisi dengan aspek ideal di sisi lainnya, sehingga komersial bukan berarti tidak bermutu, namun juga tayangan ideal bukan berarti tidak komersial. Pertanyaannya adalah, apakah mungkin?

Kita bisa belajar dari tindakan Amerika ketika membuat film serial Sesame Street pada 1969. Sesame Street adalah sebuah produksi komersial yang sengaja direkayasa untuk menghibur dan mendidik dengan mengajar anak-anak pra-sekolah untuk membaca. Program ini tergantung pada kerjasama dan kolaborasi tim serupa dengan apa yang terjadi di bidang akademik di Universitas Terbuka. Dalam masa tayangnya, Sesame Street telah dipertunjukkan di 140 negara di seluruh dunia dan telah menjadi model bagi program-program seperti Plaza Sesamo di Meksiko, flia Sesamo di Brazil, Sesamestraat di Belanda, dan Iftah Ya Simsin di Kuwait. Pada saat itu acara ini merupakan sebuah serial yang paling banyak diteliti dalam sejarah televisi. Jadi, mungkin saja sebuah tayangan ideal tetap memperhatikan sisi komersial. Demikian juga sebaliknya.

Tulisan ini hendak mengingatkan kembali bahwa anak-anak sebagai khalayak televisi memang harus dipandang sebagai kasus khusus, karena anak-anak diasumsikan mudah tersugesti dan rentan terhadap pengaruh. Oleh karena itu, regulasi dan program tayangan anak-anak harus memenuhi kriteria-kriteria tertentu. Sebetulnya, rambu-rambu sudah jelas, tinggal bagaimana itikad baik para pengelola program tayangan anak dan pengelola media mencari format yang tepat dalam memadukan antara aspek komersial dan aspek ideal tayangan anak. Banyak upaya yang bisa dilakukan. Iintinya, secara kuantitas, program tayangan anak persentasenya mesti ditingkatkan di antara tayangan-tayangan umum dan orang dewasa agar anak tidak sempat lagi melirik acaraacara seperti Smack Down atau Sinetron Picisan, kekerasan, horor, maupun infotainment, secara kualitas mengapa tidak dimulai kalau stasiunstasiun televisi mulai melirik acara-acara lokal semacam Laptop Si Unyil, Si Bolang, Kisahku, Surat Sahabat atau bahkan ide-ide lainnya dari sejumlah anak bangsa yang memang memiliki potensi untuk ini. Tentu saja, beban berat ini tidak hanya tugas para pengelola media, tapi pihak pemerintah maupun masyarakat harus ikut terlibat dalam proses ini sesuai dengan porsinya masingmasing sehingga cita-cita membuat "tayangan televisi yang sehat" bisa terwujud.

\section{Catatan Akhir}

1 Media Scene The Official guide to advertising media in Indonesia, 2005-2006.

2 Nielsen Media Research-Media Index Wave IV 2004, Wave IV 2005.

3 Media Indonesia, 2006, "Program Televisi- Anak-anak Menonton Lima Jam Sehari“. 20 Juli, Jakarta.

5 Kompas, 2006, "Bagaimana Menjelaskan Televisi kepada Anak." 24 November, Jakarta.

6 Kompas, 2006. "Hari Anak tanpa Tayangan Televisi“" 27 Juli Jakarta.

\section{Daftar Pustaka}

Burton, Graeme. 2007. Membincangkan Televisi, Terjemahan: Laily Rahmawati, Bandung, Jalasutra.

Bignell, Jonathan. 2004. An Introduction to Television Studies, New York and London, Routledge. 
Budiman, Kris. 2002. Menonton Televisi Sebagai Praktik Konsumsi: Di Depan Kotak Ajaib, Yogyakarta: Galang Pers.

Chen, Milton. 2005. Mendampingi Anak Menonton Televisi, tejemahan: Bern Hidayat. Jakarta: Gramedia.

Guntarto, B. 2000. An Assessment of Children's Television Programmes in Indonesia. Dalam Gordon Hogan (editor) "Growing Up With $T V$; Asian Chidren's Experience”, hlm 146147. Singapore: Asian Media Information and Communication Centre.

-1999. "Pengantar" dalam Nugroho, B., Eriyanto, dan Frans Sudiarsis. Politik Media Mengemas Berita. Jakarta: Institut Studi Arus Informasi.

Hoffman, Ruedi. 1999. Dasar-Dasar Apresiasi Program Televisi: Menjadikan Televisi Budaya Rakyat. Jakarta: Grassindo.

Ishadi, SK. 1999. Prospek Bisnis Informasi di Indonesia, editor Soemarsono Soemardjo, Yogyakarta: Pustaka Pelajar.

Iqbal, TM.Dhani dan Erica L.Panjaitan. 2006. Matinya Rating Televisi: Ilusi Sebuah Netralitas, Jakarta: Yayasan Obor Indonesia.

Kuswandi, Wawan. 1996. Komunikasi Massa; Sebuah Analisis Media Televisi. Jakarta: Rineka Cipta.

McQuail, Dennis. 1996. Teori Komunikasi Massa Suatu Pengantar, cetakan kedua. Jakarta: Erlangga.

Mosco, Vincent. 1996. The Political Economy of Communication. Sage Publication: New York

Mulyana. Deddy \& Idi Subandy Ibrahim. 1997. Bercinta dengan Televisi. Bandung: Remadja Rosdakarya.
Morrisan. 2005. Media Penyiaran: Strategi Mengelola Radio dan Televisi. Tangerang: Ramdina Prakarsa.

Rakhmat, Jalaluddin. 1996. Psikologi Komunikasi, edisi revisi. Bandung: Remaja Rosdakarya.

Straubhaar, Joseph \& Robert LaRose. 2004. Media Now; Understanding Media, Culture and Technology, four edition, Wadsworth: Thomson Learning Inc.

Stokes, Jane. 2006. How To Do Media and Cultural Studies; Panduan untuk Melaksanakan Penelitian dalam Kajian Media dan Budaya, Terjemahan: Santi Indra Astuti, Yogyakarta: Bentang.

\section{Sumber Lain:}

Kompas. 2006. "Hari Anak tanpa Tayangan Televisi". 27 Juli.

Mulkan, Dede. 24 November 2006. Bagaimana Menjelaskan Televisi kepada Anal-Anak?, Kompas, halaman 8.

Media Scene. 2005-2006. The Official Guide to Advertising Media in Indonesia, halaman 127.

Media Indonesia. 2006. "Program Televisi- Anakanak Menonton Lima Jam Sehari”. 20 Juli, Jakarta.

Sultani. 12 Februari 2007. "Pers Semakin Tenggelam di Dekapan Komersialisme," Kompas, halaman 5.

Susilo, Muhammad Edy. 2000. "Pemberitaan Pers Selama Masa Kampanye (Analisis Struktural terhadap Kompas dan Republika selama Kampanye Pemilu 1994)," Tesis, Program Pascasarjana, Bandung: Unpad.

"TV Penyihir Konsumsi Anak," http:// www.parasindonesia.com, retrieved : 9 Agustus 2006. 